Article

\title{
Combining Bioactive Multifunctional Dental Composite with PAMAM for Root Dentin Remineralization
}

\author{
Shimeng Xiao ${ }^{1,2}$, Kunneng Liang ${ }^{1,2}$, Michael D. Weir ${ }^{2}$, Lei Cheng ${ }^{1,2}$, Huaibing Liu ${ }^{3}$, \\ Xuedong Zhou ${ }^{1}$, Yi Ding ${ }^{1, *}$ and Hockin H. K. Xu ${ }^{2,4,5, *}$ \\ 1 State Key Laboratory of Oral Diseases, West China Hospital of Stomatology, Sichuan University, \\ Chengdu 610041, China; shimengxiao817@163.com (S.X.); kunnengliang@163.com (K.L.); \\ chengleidentist@163.com (L.C.); zhouxd@scu.edu.cn (X.Z.) \\ 2 Biomaterials and Tissue Engineering Division, Department of Endodontics, Periodontics and Prosthodontics, \\ University of Maryland School of Dentistry, Baltimore, MD 21201, USA; mweir@umaryland.edu \\ 3 L.D. Caulk Division, Dentsply Sirona Restorative, Milford, DE 19963, USA; \\ Huaibing.Liu@dentsplysirona.com \\ 4 Center for Stem Cell Biology \& Regenerative Medicine, University of Maryland School of Medicine, \\ Baltimore, MD 21201, USA \\ 5 Department of Mechanical Engineering, University of Maryland, Baltimore County, MD 21250, USA \\ * Correspondence: yidingscu@163.com (Y.D.); hxu@umaryland.edu (H.H.K.X.); \\ Tel.: +86-186-0287-5710 (Y.D.); +1-410-706-7047 (H.H.K.X.)
}

Academic Editor: Franz Weber

Received: 5 December 2016; Accepted: 17 January 2017; Published: 22 January 2017

\begin{abstract}
Objectives. The objectives of this study were to: (1) develop a bioactive multifunctional composite (BMC) via nanoparticles of amorphous calcium phosphate (NACP), 2-methacryloyloxyethyl phosphorylcholine (MPC), dimethylaminohexadecyl methacrylate (DMAHDM) and nanoparticles of silver (NAg); and (2) investigate the effects of combined BMC + poly (amido amine) (PAMAM) on remineralization of demineralized root dentin in a cyclic artificial saliva/lactic acid environment for the first time. Methods. Root dentin specimens were prepared and demineralized with $37 \%$ phosphoric acid for $15 \mathrm{~s}$. Four groups were prepared: (1) root dentin control; (2) root dentin with BMC; (3) root dentin with PAMAM; (4) root dentin with BMC + PAMAM. Specimens were treated with a cyclic artificial saliva/lactic acid regimen for 21 days. Calcium $(\mathrm{Ca})$ and phosphate $(\mathrm{P})$ ion concentrations and acid neutralization were determined. The remineralized root dentin specimens were examined via hardness testing and scanning electron microscopy (SEM). Results. Mechanical properties of BMC were similar to commercial control composites $(p=0.913)$. BMC had excellent $\mathrm{Ca}$ and $\mathrm{P}$ ion release and acid-neutralization capability. BMC or PAMAM alone each achieved slight mineral regeneration in demineralized root dentin. The combined BMC + PAMAM induced the greatest root dentin remineralization, and increased the hardness of pre-demineralized root dentin to match that of healthy root dentin $(p=0.521)$. Significance. The excellent root dentin remineralization effects of BMC + PAMAM were demonstrated for the first time. BMC + PAMAM induced effective and complete root dentin remineralization in an acid challenge environment. The novel BMC + PAMAM method is promising for Class $\mathrm{V}$ and other restorations to remineralize and protect tooth structures.
\end{abstract}

Keywords: root dentin; root caries; multifunctional composite; acid challenge; calcium phosphate nanoparticles; poly (amido amine)

\section{Introduction}

Dental caries is a prevalent and worldwide burden [1-4]. Acid-producing bacteria feed on fermentable carbohydrates and produce organic acids as byproducts [5]. The acids dissolve 
hydroxyapatite minerals, leading to caries lesions [6]. Remineralization is the natural repair process for caries lesions in vivo [7]. However, natural remineralization in vivo can only overcome a certain level of caries (acid) challenges. When bacterial acid challenge is severe, natural remineralization is insufficient to halt or reverse the caries process [7]. Therefore, the development of novel antibacterial and remineralization dental materials is needed to help combat caries and protect tooth structures.

Composites are widely used as filling materials due to their esthetics and direct-filling capabilities [8-10]. However, previous studies showed that composites are challenged with the accumulation of more biofilms and plaque than other restorative materials [11,12], which could result in secondary caries at the composite-tooth margins. Furthermore, the prevalence and severity of tooth root caries increases with aging, from $7 \%$ among young people to $56 \%$ in seniors of $\geq 75$ years of age [13]. This is a growing public health issue due to the rapid increase in the elderly population along with increases in tooth retention in seniors [14,15]. Gingival recession due to aging, periodontal disease or traumatic tooth-brushing habits can increase the susceptibility to root caries [16]. Furthermore, low salivary flow in seniors and patients with dry mouths further contribute to biofilm and plaque buildup and the occurrence of root caries. Root caries can be treated with Class V restorations. However, restorations with subgingival margins are difficult to clean, which in turn could enhance the development of periodontitis and the loss of the tooth's attachment [10]. Therefore, there is a need to develop a bioactive Class V composite to combat secondary caries and root caries.

To inhibit caries, nanoparticles of amorphous calcium phosphate (NACP) were incorporated into composite with calcium $(\mathrm{Ca})$ and phosphate $(\mathrm{P})$ ion release [17], which could remineralize tooth lesions [18]. The NACP nanocomposite was "smart" to increase the ion release at cariogenic $\mathrm{pH}$ when these ions were most needed, and could rapidly neutralize acid challenges to raise a cariogenic $\mathrm{pH}$ of 4 to a safe $\mathrm{pH}$ of 6 [19]. In addition, quaternary ammonium methacrylates (QAMs) have been incorporated into resins to achieve antibacterial functions to reduce biofilm acids [20-23]. The antibacterial activity of QAMs was shown to increase with increasing the alkyl chain length (CL) from 5 to 16 for the ammonium groups [24,25]. A recent study demonstrated that a composite containing dimethylaminohexadecyl methacrylate (DMAHDM) with CL of 16 had a strong antimicrobial function [25].

Protein-repellent resins represent another approach to biofilm reduction. Salivary protein coating on the resin could decrease the efficacy of "contact-inhibition" via QAMs [26]. Therefore, it would be desirable to develop protein-repellent functions that can reduce protein adsorption and enhance contact-inhibition. A previous study showed 2-metha-cryloyloxyethyl phosphorylcholine (MPC) could resist protein adsorption and bacterial adhesion $[27,28]$. Recently, MPC was incorporated into dental resins showing strong protein-repellent properties and inhibition against oral bacteria $[22,29,30]$. Furthermore, resins containing silver (Ag) nanoparticles (NAg) were reported to also have a potent antibacterial activity [31-33]. Incorporating NAg with small particle sizes and a high surface area into resin achieved a strong antimicrobial function [34,35]

To remineralize tooth lesions, poly (amido amine) (PAMAM) dendrimer was important for remineralization [36-38]. Several types of PAMAM dendrimers were used as nucleation templates to induce tooth remineralization in tooth structures [36-38]. PAMAM is an excellent nucleation template and can rapidly absorb $\mathrm{Ca}$ and $\mathrm{P}$ ions to cause remineralization [36-38]. However, these aforementioned approaches have not been combined to develop a bioactive Class $\mathrm{V}$ composite for treating root caries.

In our recent study, a Class V composite with NACP, DMAHDM and MPC was developed and effectively inhibited biofilms of periodontal pathogens [10]. However, the remineralization capability of this new composite was not investigated. In another study, the combined PAMAM plus NACP composite approach was shown to induce effective dentin remineralization in a cyclic artificial saliva/lactic acid regimen [39]. The combination of PAMAM and NACP achieved triple benefits of excellent nucleation template, high concentration of $\mathrm{Ca}$ and $\mathrm{P}$ ions, and acid-neutralization. However, to date, there has been no report on the remineralization effects of PAMAM + NACP composite on 
tooth root dentin. Furthermore, there has been no report on the combination of PAMAM, NACP, DMADHM, MPC and NAg to achieve strong antibacterial and remineralization capabilities.

Therefore, the objectives of the present study were to: (1) develop a new bioactive multifunctional composite (BMC) with NACP, DMADHM, MPC and NAg for Class V restorations; and (2) investigate the effects of BMC, PAMAM, and BMC + PAMAM on root dentin remineralization for the first time. It was hypothesized that: (1) BMC would greatly increase $\mathrm{Ca}$ and $\mathrm{P}$ concentrations, neutralize acid and promote root dentin remineralization in a cyclic artificial saliva/acid treatment; (2) PAMAM would remineralize the demineralized root dentin in cyclic artificial saliva/lactic acid regimen; (3) The combined BMC + PAMAM approach would induce the greatest root dentin remineralization among the test groups.

\section{Materials and Methods}

\subsection{Preparation of Bioactive Multifunctional Composite (BMC)}

Ethoxylated bisphenol A dimethacrylate (EBPADMA, Sigma-Aldrich, St. Louis, MO, USA) and pyromellitic dianhydride glycerol dimethacrylate (PMDGDM, Esstech, Essington, PA, USA) were mixed at 1:1 mass ratio, following a previous study [40]. It was rendered light-curable with $0.2 \%$ camphorquinone and $0.8 \%$ ethyl $4-\mathrm{N}, \mathrm{N}$-dimethylaminobenzoate (all by mass, unless noted otherwise) [40]. This EBPADMA-PMDGDM resin is referred to as EBPM.

Silver 2-ethylhexanoate (Strem, Newburyport, MA, USA) of $0.12 \mathrm{~g}$ was dissolved into $0.88 \mathrm{~g}$ of 2-(tert-butylamino)ethyl meth-acrylate (TBAEMA, Sigma-Aldrich, St. Louis, MO, USA) [41]. TBAEMA could facilitate Ag-salt dissolution in resin [42]. Of this solution, $1 \%$ was added to EBPM resin to form EBPM-NAg resin, yielding $0.12 \%$ of Ag salt in resin following previous studies [41,42].

MPC was obtained commercially (Sigma-Aldrich, St. Louis, MO, USA) which was synthesized using a method reported previously [28]. MPC is a methacrylate with a phospholipid polar group in the side chain [28]. MPC was incorporated into the EBPM-NAg resin, yielding a 3\% MPC content in the final composite.

DMAHDM was synthesized using a modified Menschutkin reaction in which a tertiary amine group was reacted with an organohalide [43]. Briefly, $10 \mathrm{mmol}$ of 2-(dimethylamino)ethyl methacrylate (DMAEMA, Sigma-Aldrich, St. Louis, MO, USA) and $10 \mathrm{mmol}$ of 1-bromohexadecane (BHD, TCI America, Portland, OR, USA) were combined with $3 \mathrm{~g}$ of ethanol in a $20 \mathrm{~mL}$ scintillation vial. The vial was stirred at $70{ }^{\circ} \mathrm{C}$ for $24 \mathrm{~h}$. The solvent was then removed via evaporation, yielding DMAHDM as a clear, colorless, and viscous liquid [44]. DMAHDM was mixed with EBPM-NAg-MPC resin, yielding a DMAHDM mass fraction of $3 \%$ in the final composite.

NACP were synthesized using a spray-drying technique as previously described [17]. Briefly, calcium carbonate and dicalcium phosphate anhydrous were dissolved in acetic acid to produce $\mathrm{Ca}$ and $\mathrm{P}$ concentrations of $8 \mathrm{mmol} / \mathrm{L}$ and $5.333 \mathrm{mmol} / \mathrm{L}$, respectively, thus yielding a Ca/P molar ratio of 1.5, the same as that for ACP $\left[\mathrm{Ca}_{3}\left(\mathrm{PO}_{4}\right)_{2}\right]$. This solution was sprayed into a heated chamber of the spray-drying machine. An electrostatic precipitator was used to collect the dried particles. This produced NACP with a mean particle size of $116 \mathrm{~nm}$ [17]. Barium boroaluminosilicate glass particles with a median size of $1.4 \mu \mathrm{m}$ were used as a co-filler (Caulk/Dentsply, Milford, DE, USA), which was silanized with $4 \% 3$-methacryloxypropyltrimethoxysilane and $2 \%$ npropylamine [17]. NACP was incorporated into the EBPM-NAg-MPC-DMADHM resin at a NACP filler mass fraction of $30 \%$ in the final composite, while the glass particle filler level was $35 \%$. The mixed composite paste was placed into a mold of $2 \mathrm{~mm} \times 2 \mathrm{~mm} \times 25 \mathrm{~mm}$, and light-cured (Triad 2000, Dentsply, York, PA, USA) for $1 \mathrm{~min}$ on each open side. In the composite, the final mass fractions of MPC, DMADHM, NACP, glass filler and EBPM-NAg resin matrix were 3\%, 3\%, 30\%, 35\% and 29\%, respectively. Two experimental composites were fabricated: 
(1) Antibacterial and remineralizing composite: 3\% MPC + 3\% DMAHDM + 30\% NACP + 35\% glass fillers + 29\% EBPM-NAg resin matrix (referred to as "bioactive multifunctional composite", or "BMC");

(2) Experimental control without antibacterial agents: 30\% NACP + 35\% glass fillers + 35\% EBPM resin matrix (referred to as "EBPM + NACP" composite).

In addition, two commercial composites served as controls in mechanical testing. Heliomolar is a nanocomposite that contained silica and ytterbium-trifluoride fillers with particle sizes of 40-200 nm at a filler level of $66.7 \%$. Heliomolar was selected because it is indicated for Class I and II restorations as well as Class V restorations for root caries, Heliomolar served as control I. Another nanocomposite (Renamel Microfill, Cosmedent, Chicago, IL, USA) served as control II. It consisted of fillers of $40 \mathrm{~nm}$ to 200 micron at $60 \%$ filler level by volume in a multifunctional resin of diurethane dimethacrylate and butanediol dimethacrylate. Renamel was selected because it is indicated for Class III, IV, and V restorations. All specimens were light-cured in the same manner as described above.

\subsection{PAMAM Synthesis}

PAMAM dendrimers were synthesized as described previously [45]. Briefly, the divergent synthesis of PAMAM dendrimers included a two-step interactive sequence to produce amine-terminated structures. Iterative sequencing involved alkylation with methyl acrylate (MA) followed by amidation with excess 1,2-ethylenediamine (EDA). The alkylation step produced ester-terminated intermediates that were called "half-generations". The second step involved amidation of the ester-terminated intermediates with a large excess of EDA to produce amine terminated intermediates, which were called "full-generations". The first and second generations are linear molecules, while the third generation is a sphere molecule with more functional groups, which ensures that it could absorb more $\mathrm{Ca}$ and $\mathrm{P}$ ions during remineralization. The present study used the third generation PAMAM- $\mathrm{NH}_{2}$, which was obtained commercially (Chenyuan Dendrimer Tech., Weihai, China). Previous studies showed that PAMAM- $\mathrm{NH}_{2}$ effectively remineralized the demineralized dentin [46]. In this article, the term "PAMAM" refers to the third generation PAMAM-NH $\mathrm{N}_{2}$. The PAMAM solution was prepared by dissolving $100 \mathrm{mg}$ of PAMAM powder in $100 \mathrm{~mL}$ of distilled water to achieve a concentration of $1 \mathrm{mg} / \mathrm{mL}$, following a previous study [37].

\subsection{Mechanical Testing}

All composite specimens were stored at $37^{\circ} \mathrm{C}$ for $24 \mathrm{~h}$, and then fractured in three-point flexure with a $10 \mathrm{~mm}$ span at a crosshead-speed of $1 \mathrm{~mm} / \mathrm{min}$ on a computer-controlled Universal Testing Machine (5500R, MTS, Cary, NC, USA) [17]. Flexural strength (S) was calculated as: $S=3 P_{\max } L /\left(2 b h^{2}\right)$, where $P$ is the fracture load, $L$ is span, $b$ is specimen width and $h$ is thickness. Elastic modulus $(E)$ was calculated as: $E=(P / d)\left(L^{3} /\left(4 b h^{3}\right)\right)$, where load $P$ divided by displacement $d$ is the slope in the linear elastic region [17].

\subsection{Preparation of Root Dentin Specimens}

Caries-free and single-rooted human permanent premolars were collected from the dental school clinics following a protocol approved by the University of Maryland Institutional Review Board. Teeth were disinfected in a $0.005 \%$ promodyne solution for $4 \mathrm{~h}$ and stored at $4{ }^{\circ} \mathrm{C}$ in distilled water. Root dentin squares of $4 \mathrm{~mm} \times 4 \mathrm{~mm} \times 1 \mathrm{~mm}$ were prepared by cutting parallel to the long axis of the tooth $2 \mathrm{~mm}$ below the cemento-enamel junction using a diamond blade (Buehler, Lake Bluff, IL, USA). The root dentin specimens were acid-etched with $37 \%$ phosphoric acid for $15 \mathrm{~s}$ to create demineralization, following a previous study [47]. This acid etching method was used in order to investigate the remineralization of demineralized dentin with a large amount of exposed collagen fibrils and prevent secondary caries at the bonded dentin-restoration interface [47]. The demineralized 
root dentin specimens were sonicated in distilled water for $10 \mathrm{~min}$ to remove any debris and then stored at $4{ }^{\circ} \mathrm{C}$ in phosphate-buffered saline (PBS, pH 7.4) before use.

\subsection{Root Dentin Remineralization in an Acid Challenge Environment}

The demineralized tooth root dentin specimens were randomly divided into four groups:

(1) Control group. Each demineralized root dentin specimen was coated with $100 \mu \mathrm{L}$ of distilled water, and then air dried to serve as a negative control [37].

(2) BMC group. Each demineralized root dentin specimen was placed in contact with three BMC bars of $2 \mathrm{~mm} \times 2 \mathrm{~mm} \times 12 \mathrm{~mm}$ [35]. Three bars were used because, when subsequently immersed in $1 \mathrm{~mL}$ solution; this would yield a composite volume/solution volume ratio of $0.14 / 1$, the same as that in a previous study [35].

(3) PAMAM group. Each demineralized root dentin specimen was coated with $100 \mu \mathrm{L}$ of the PAMAM solution which was kept on dentin for $1 \mathrm{~h}$ to ensure that PAMAM macromolecules were immobilized on root dentin, and then the specimen was rinsed with water to remove any loose PAMAM [37].

(4) BMC + PAMAM group. Each demineralized root dentin specimen was first coated with $100 \mu \mathrm{L}$ of PAMAM solution, and then three BMC bars of $2 \mathrm{~mm} \times 2 \mathrm{~mm} \times 12 \mathrm{~mm}$ were placed on root dentin specimen.

Six specimens were tested for each group $(n=6)$. A $1.5 \mathrm{~mL}$ conical vial was used to store each sample which was completely immersed in $1 \mathrm{~mL}$ of a solution below. Artificial saliva solution was prepared by dissolving, in distilled water, $1.5 \mathrm{mmol} / \mathrm{L} \mathrm{CaCl}_{2}, 0.9 \mathrm{mmol} / \mathrm{L} \mathrm{KH}_{2} \mathrm{PO}_{4}, 130 \mathrm{mmol} / \mathrm{L} \mathrm{KCl}$, $1.0 \mathrm{mmol} / \mathrm{L} \mathrm{NaN}_{3}$ and $20 \mathrm{mmol} / \mathrm{L}$ 4-(2-hydroxyethyl)-1-piperazineethanesulfonic acid (HEPES), and adjusting to $\mathrm{pH} 7.0$ with $\mathrm{KOH}(1 \mathrm{mmol} / \mathrm{L})$ [48]. Artificial saliva is a solution to mimic the human saliva, which can supply $\mathrm{Ca}$ and $\mathrm{P}$ ions for the remineralization [48]. In addition, a sodium chloride $(\mathrm{NaCl})$ solution $(133 \mathrm{mmol} / \mathrm{L})$ was buffered to $\mathrm{pH} 4$ with $50 \mathrm{mmol} / \mathrm{L}$ lactic acid to simulate accelerated cariogenic conditions (referred to as "lactic acid solution") [17]. Each day, each specimen of the aforementioned four groups was immersed in $1 \mathrm{~mL}$ of fresh artificial saliva for $23 \mathrm{~h}$, and then in $1 \mathrm{~mL}$ of lactic acid solution for $1 \mathrm{~h}$ at $37^{\circ} \mathrm{C}$, following previous studies [18]. This was repeated for 21 days.

\subsection{Ca and P Ion Concentrations Measurement}

At $1,3,5,7,10,14$ and 21 days, the $\mathrm{Ca}$ and $\mathrm{P}$ ion concentrations in the lactic acid and artificial saliva solutions were measured. At each time, the $1 \mathrm{~mL}$ solution was removed and replaced by fresh solution. The collected solution was analyzed for $\mathrm{Ca}$ and $\mathrm{P}$ ion concentrations via a spectrophotometric method (DMS-80 UV-visible, Varian, Palo Alto, CA, USA) using known standards and calibration curves, following previous studies [49].

\subsection{Acid Neutralization}

At $1,3,5,7,10,14$ and 21 days, the $\mathrm{pH}$ values of lactic acid solutions of the four groups were measured. Every day, each sample was immersed in the artificial saliva solution for $23 \mathrm{~h}$, and in the lactic acid solution for $1 \mathrm{~h}$. During that $1 \mathrm{~h}$ in lactic acid solution, the $\mathrm{pH}$ was monitored with a combination $\mathrm{pH}$ electrode (Orion, Cambridge, MA, USA). The $\mathrm{pH}$ in artificial saliva was also measured.

\subsection{Dentin Hardness Measurement}

Dentin hardness was related to the amount of minerals in the dentin structure; hence, surface hardness was usually measured to evaluate the remineralization extent [27]. The hardness of dentin was measured for the four groups after 21 days. A hardness tester (Tukon 2100B, Instron, Canton, MA, USA) was used with a Vickers diamond indenter at a load of $20 \mathrm{~g}$ and a dwell time 
of $10 \mathrm{~s}$ [27]. Six indentations were made in each dentin, and six dentin specimens were tested for each group. In addition, hardness values of sound healthy dentin without acid treatment, and dentin after acid-etching but without the 21 days of immersion treatment, were also measured as comparative controls.

\subsection{Scanning Electron Microscopic (SEM) Examination}

After 21 days, all root dentin squares were removed from the solutions to examine whether there were minerals regenerated in the demineralized root dentin surface and in the dentinal tubules. The root dentin square was cut with a diamond saw (Buehler, Lake Bluff, IL, USA) into two halves along the midline. One half was used for observing the occlusal section (the observed surface was perpendicular to the tubule axis). The other half was used for observing the longitudinal section (the observed surface was parallel to the tubule axis). The root dentin samples were sonicated in water for 10 min to remove the debris caused by the cutting. They were then immersed in 1\% glutaraldehyde in PBS for $4 \mathrm{~h}$ at 4 ${ }^{\circ} \mathrm{C}$. They were rinsed with PBS and subjected to graded ethanol dehydrations, and then rinsed with 100\% hexamethyldisilazane [19]. Then the root dentin samples were sputter-coated with gold and examined via scanning electron microscopy (SEM, JEOL 5300, Peabody, MA, USA).

\subsection{Statistical Analysis}

All data were checked for normal distribution with the Kolmogorov-Smirnov test. For power analysis and specimen size, our previous and preliminary studies indicated typical standard deviations of about $10 \%-30 \%$ of the mean. The differences between control and remineralizing groups on $\mathrm{Ca}$ and $\mathrm{P}$ ions and dentin hardness are expected to be at least $100 \%$. A 5\% confidence level and a power to detect a treatment effect of $95 \%$ let to the use of $n=6$. One-way and two-way analyses of variance (ANOVA) were performed to detect the significant effects of the variables. Tukey's multiple comparison tests were used at a $p$ value of 0.05 .

\section{Results}

The mechanical properties of composites are plotted in Figure 1A (flexural strength), and Figure 1B (elastic modulus) (mean $\pm \mathrm{SD} ; n=6$ ). Flexural strength and elastic modulus of BMC were not significantly different from those of commercial control composites $(p=0.913)$, suggesting that BMC could potentially be used in restorations where Heliomolar and Renamel are used, with the benefits of containing MPC and DMAHDM for antibacterial activity, and NACP for remineralization.
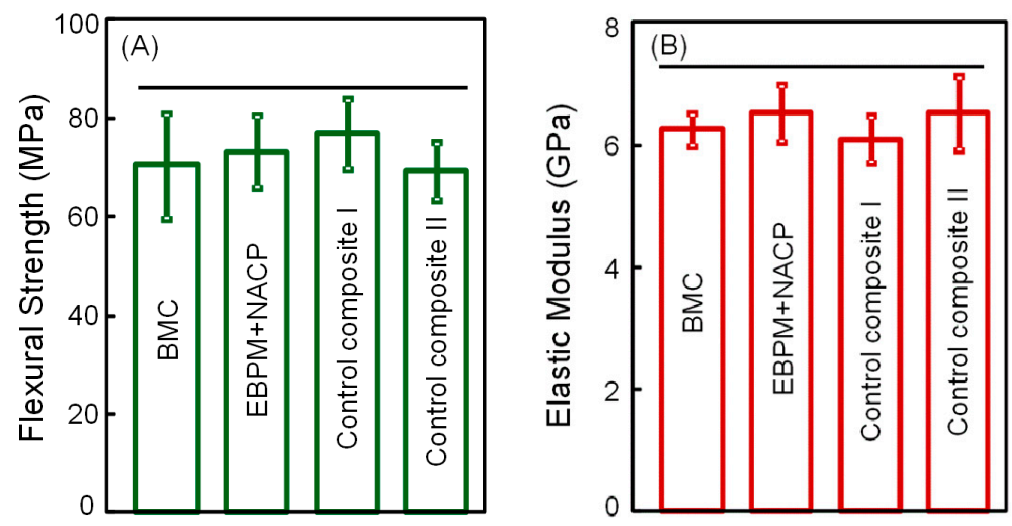

Figure 1. Mechanical properties of composites: (A) Flexural strength, and (B) elastic modulus (mean $\pm \mathrm{SD} ; n=6$ ). Bioactive multifunctional composite (BMC) had flexural strength and elastic modulus similar to EBPADMA-PMDGDM (EBPM) + nanoparticles of amorphous calcium phosphate (NACP) composite and commercial control composites. Horizontal line indicates values that are not significantly different $(p=0.875)$. 
$\mathrm{Ca}$ and $\mathrm{P}$ ion concentrations for the four groups are plotted in Figure 2A,C (artificial saliva), and Figure 2B,D (lactic acid solution) (mean $\pm \mathrm{SD} ; n=6$ ). For artificial saliva, the $\mathrm{Ca}$ and $\mathrm{P}$ concentrations of BMC and BMC + PAMAM groups were significantly higher than PAMAM and control groups $(p=0.009)$. For lactic acid solution, the $\mathrm{Ca}$ and $\mathrm{P}$ ion concentrations were nearly zero for PAMAM and control groups. In contrast, the $\mathrm{Ca}$ and $\mathrm{P}$ concentrations were also higher for $\mathrm{BMC}$ and $\mathrm{BMC}+$ PAMAM groups due to ion release from BMC nanocomposite. While ion concentrations decreased from 1 to 21 days due to the change of a fresh solution each day, BMC and BMC + PAMAM groups at 21 days still had significantly higher ion concentrations than PAMAM and control groups $(p=0.014)$, indicating continued ion release from BMC nanocomposite.
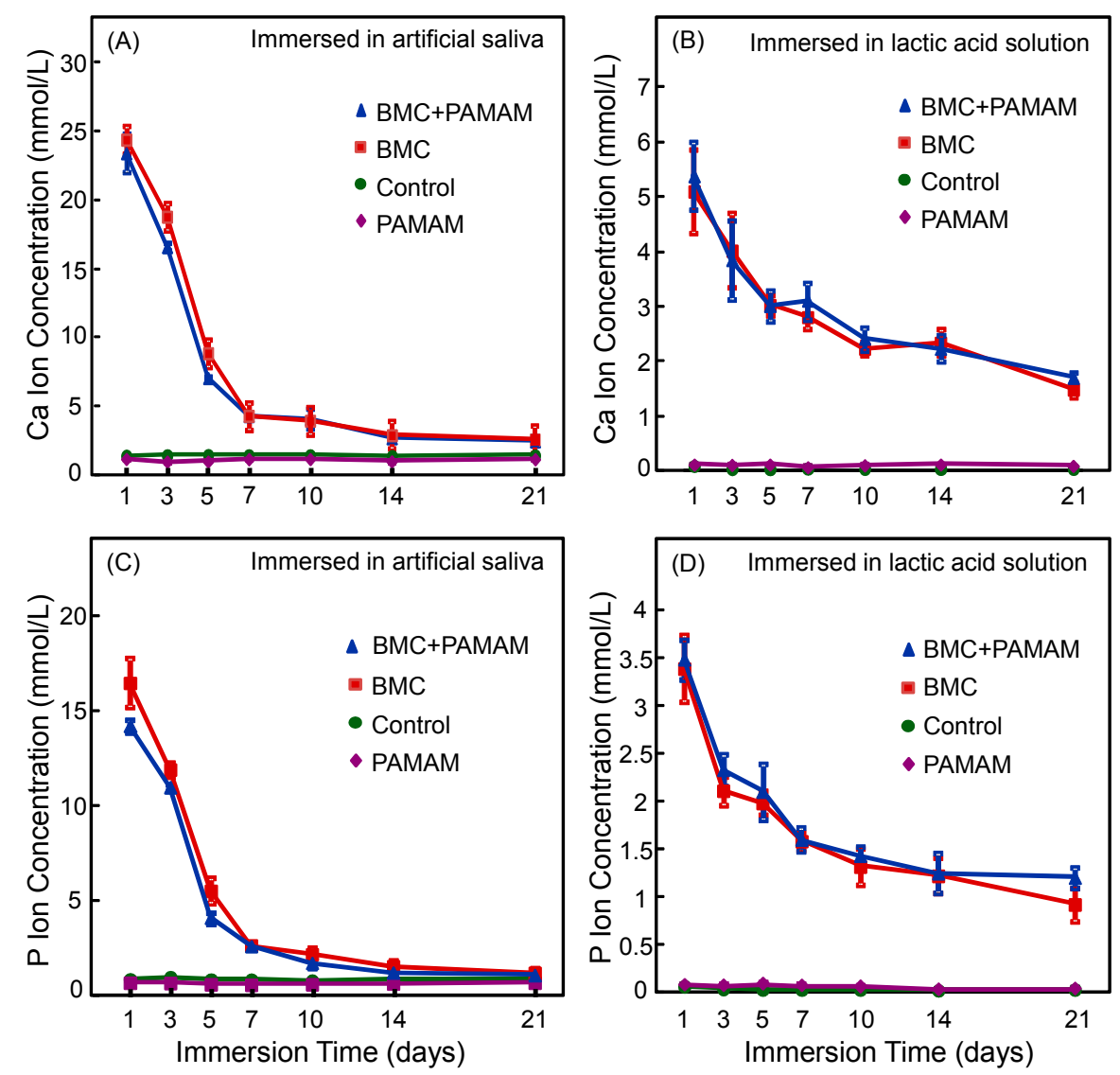

Figure 2. $\mathrm{Ca}$ and $\mathrm{P}$ ion concentrations (mean $\pm \mathrm{SD} ; n=6)$. (A,C) $\mathrm{Ca}$ and $\mathrm{P}$ concentrations in artificial saliva, (B,D) Ca and $\mathrm{P}$ ion concentrations in lactic acid. The BMC group and BMC + poly (amido amine) (PAMAM) group had much higher $\mathrm{Ca}$ and $\mathrm{P}$ ion concentrations than PAMAM and control groups. For BMC and BMC + PAMAM groups, the ion concentrations decreased with time because every day a fresh solution was used to immerse the specimens.

Specimens of the four groups were immersed in artificial saliva at $\mathrm{pH} 7$ for $23 \mathrm{~h}$, and in $\mathrm{pH} 4$ lactic acid solution for $1 \mathrm{~h}$ every day. The $\mathrm{pH}$ values of the lactic acid are plotted in Figure 3 , with $\mathrm{pH}$ being measured (A) at $15 \mathrm{~min}$, and (B) at $60 \mathrm{~min}$, after the specimen was immersed in the solution (mean $\pm \mathrm{SD} ; n=6$ ). For PAMAM and control group, the $\mathrm{pH}$ stayed at 4 . In contrast, for BMC and $\mathrm{BMC}+$ PAMAM groups, at 1 day, the $\mathrm{pH}$ was increased to 6.3 at $15 \mathrm{~min}$ and 6.5 at $60 \mathrm{~min}$. The $\mathrm{pH}$ showed a slight decrease with increasing the number of days because a fresh $\mathrm{pH} 4$ solution was used each day to immerse the sample. At 21 days, the $\mathrm{pH}$ reached 5.4 at $15 \mathrm{~min}$, and 5.7 at $60 \mathrm{~min}$. These $\mathrm{pH}$ values are much higher than the $\mathrm{pH} 4$ of the groups without $\mathrm{BMC}(p=0.005)$. 

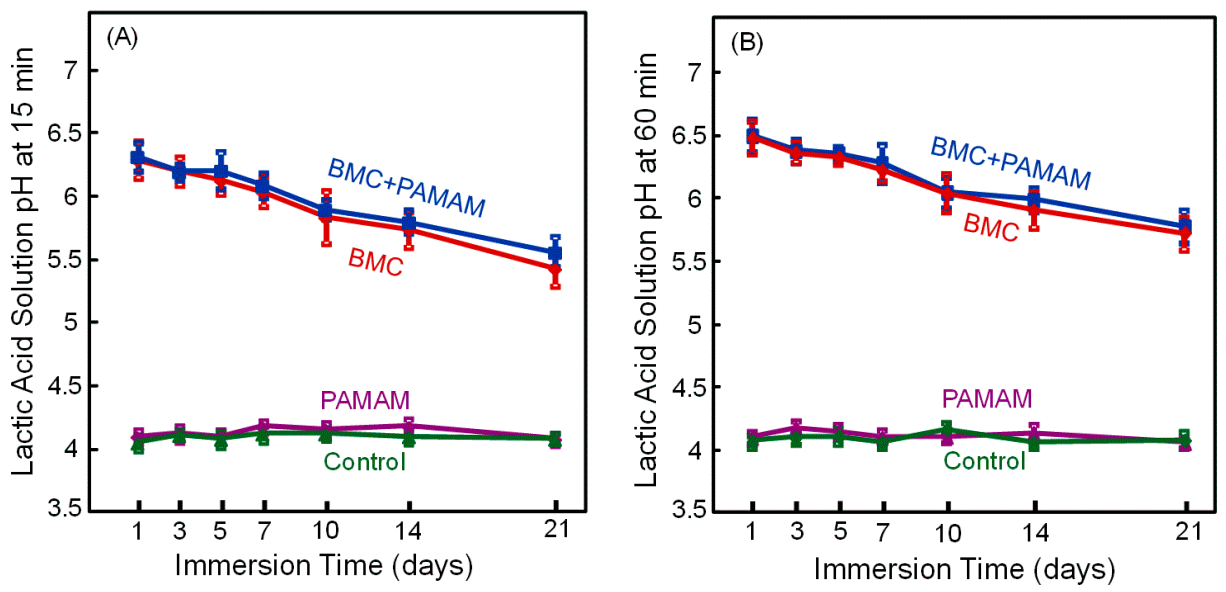

Figure 3. Acid neutralization. The $\mathrm{pH}$ of lactic acid solution was measured after the specimen was immersed for: (A) $15 \mathrm{~min}$, and (B) $60 \mathrm{~min}$ (mean $\pm \mathrm{SD} ; n=6$ ). This was done for 21 days. The BMC group and $\mathrm{BMC}+$ PAMAM group neutralized the acid and raised the $\mathrm{pH}$. PAMAM and control groups had no acid neutralization and the $\mathrm{pH}$ stayed near 4.

The root dentin hardness values are plotted in Figure 4 (mean $\pm S D ; n=6)$. The hardness of healthy sound root dentin was $0.58 \pm 0.06 \mathrm{GPa}$. After demineralization with $37 \%$ phosphoric acid, root dentin hardness decreased to $0.35 \pm 0.03 \mathrm{GPa}(p=0.015)$. After 21 days of the cyclic artificial saliva/lactic acid regimen, root dentin hardness of control group decreased to $0.29 \pm 0.05 \mathrm{GPa}$. In contrast, BMC or PAMAM alone yielded greater dentin hardness, which was $0.43 \pm 0.05$ and $0.45 \pm 0.04 \mathrm{GPa}$, respectively. BMC + PAMAM had the greatest root dentin hardness of $0.55 \pm 0.04 \mathrm{GPa}$, which approached that of sound root dentin $(p=0.521)$.

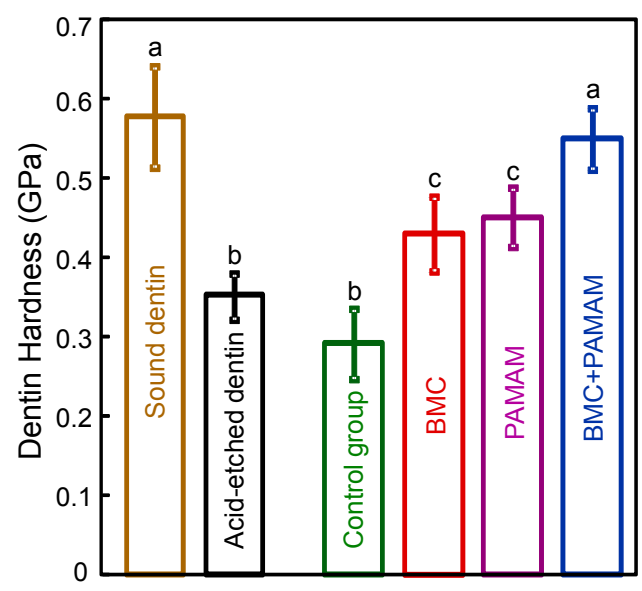

Figure 4. Hardness of root dentin. Healthy untreated root dentin and acid-etched root dentin were included for comparison. Four groups were measured after 21 days of artificial saliva/lactic acid regimen treatment: Control, BMC group, PAMAM group, and BMC + PAMAM group. Dissimilar letters indicate significantly different values $(p=0.022)$.

Representative SEM micrographs of root dentin sections perpendicular to the tubules are shown in Figure 5. For control group, there were no minerals regenerated on the demineralized root dentin surface. BMC and PAMAM showed moderate remineralization, characterized by minerals precipitated in root dentin surfaces. In contrast, BMC + PAMAM showed the greatest remineralization, with much greater mineral growth than PAMAM or BMC alone. 

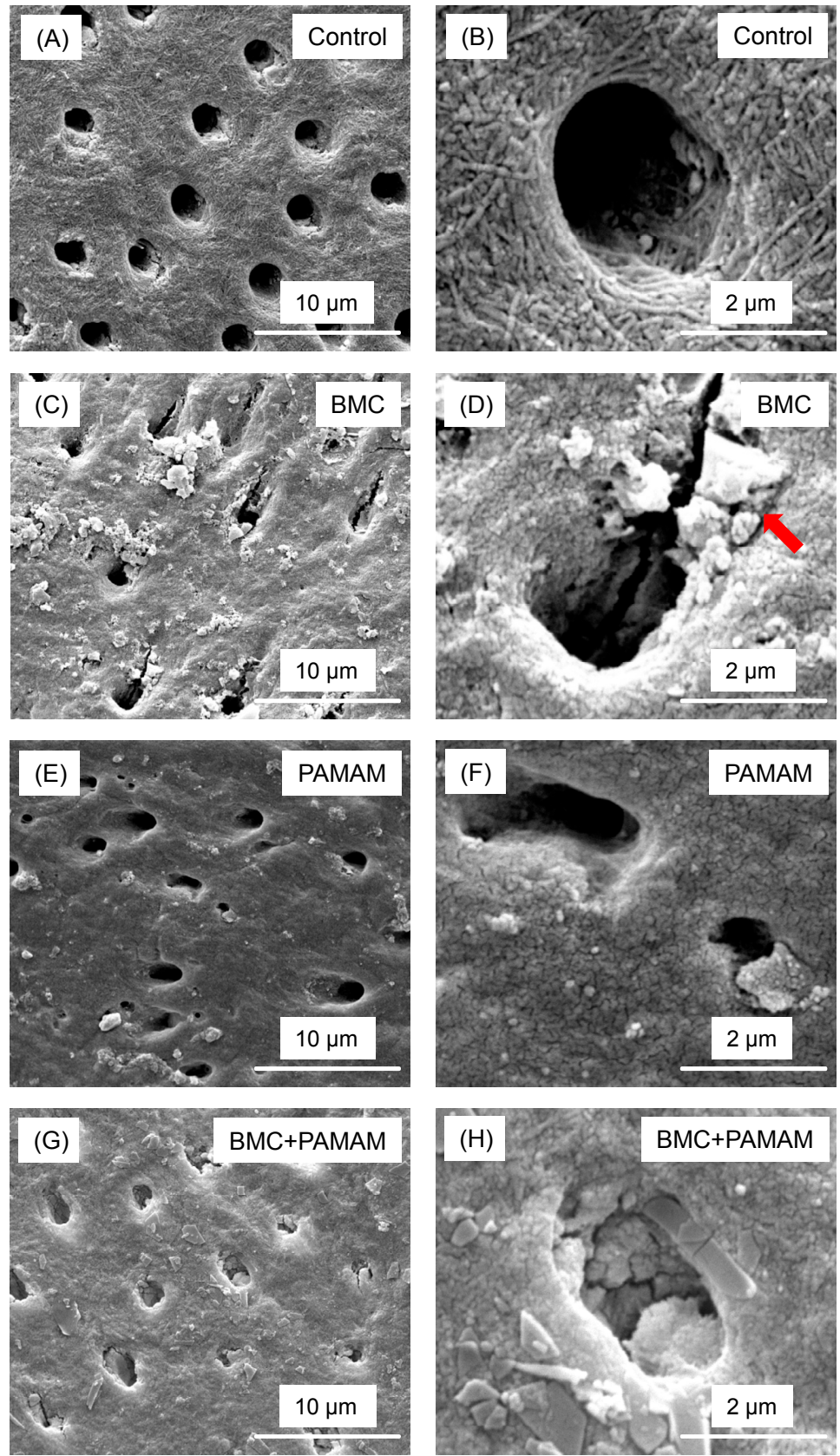

Figure 5. Representative SEM images of demineralized root dentin surface perpendicular to tubule axis after 21 days cyclic artificial saliva/lactic acid regimen: (A,B) control group, (C,D) BMC group, (E,F) PAMAM group, and (G,H) BMC + PAMAM group. Left column is at a lower magnification. Right column is at a higher magnification. Exposed collagen fibrils were detected in (A,B). (C-F) showed that regenerated minerals precipitated on the root dentin surface. Arrows showed minerals partially occluding the dentinal tubules. In $(\mathbf{G}, \mathbf{H})$, the dentin was covered by the remineralized mineral crystals.

Representative SEM micrographs of root dentin parallel to the tubules are shown in Figure 6. All pictures were taken on root dentin cross-sections in a subsurface region of 2-30 $\mu \mathrm{m}$ beneath the external surface. For control group, empty dentinal tubules were clearly observed. In contrast, for BMC and PAMAM groups, minerals were deposited in the dentinal tubules. The greatest mineral regeneration in root tubules was achieved via BMC + PAMAM. 

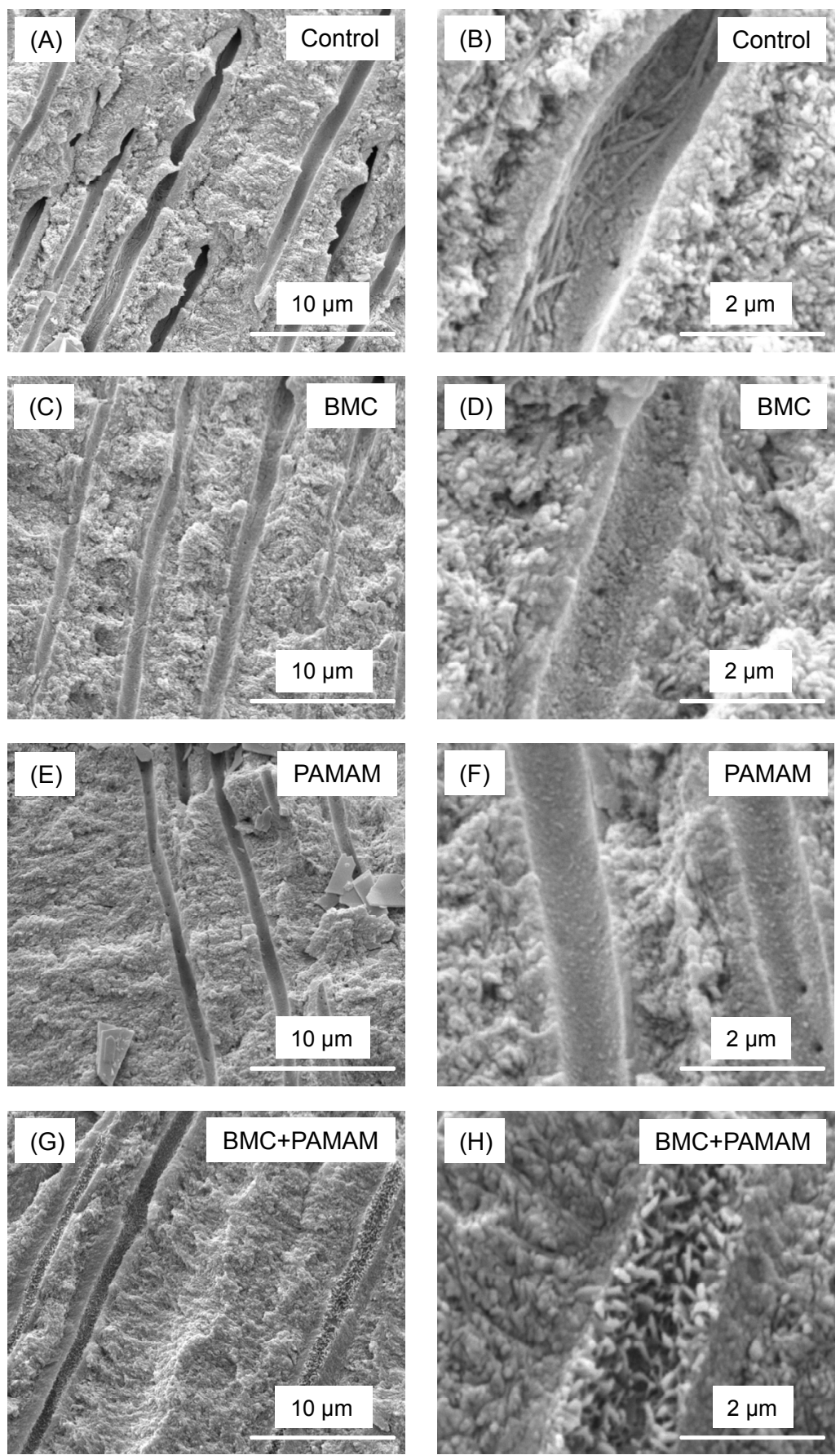

Figure 6. Representative scanning electron microscopy (SEM) images of demineralized root dentin subsurface cross-section parallel to tubule axis after 21 days cyclic artificial saliva/lactic acid regimen: (A,B) control; (C,D) BMC group; (E,F) PAMAM group; and $(\mathbf{G}, \mathbf{H})$ BMC + PAMAM. Left column is a lower magnification. Right column is a higher magnification. Exposed collagen fibrils were detected in $(\mathbf{A}, \mathbf{B})$. (C-F) show that minerals precipitated in tubules. In $(\mathbf{G}, \mathbf{H})$, the dentinal tubules were occluded by a great amount of the remineralized minerals.

\section{Discussion}

The present study developed a bioactive multifunctional composite (BMC) containing NAg, MPC, DMAHDM and NACP, and combined this composite with PAMAM to combat tooth caries for the first time. This approach achieved excellent root dentin remineralization. As an example, 
for Class V restorations, the new bioactive composite and the combination with PAMAM are potentially applicable to other types of restorations. Previous studies showed that a composite containing MPC, DMAHDM and NACP was effective to inhibit periodontitis-related pathogens for subgingival Class $\mathrm{V}$ restorations [10]. The new method in the present study remineralized the demineralized root dentin in a cyclic artificial saliva/lactic acid regimen. The hypotheses were proven that adding NAg, MPC, DMAHDM and NACP did not compromise the mechanical properties, and that BMC combined with PAMAM was the most effective method to inhibit demineralization and promote remineralization for tooth root dentin.

A previous study showed that a novel NACP composite containing QADM and NAg had strong antibacterial capability that was maintained after 12 months of water-aging [34], and the mechanical properties of the bioactive composite matched those of commercial control composites without antibacterial properties [34]. BMC may also sustain its good mechanical properties and antibacterial properties. First, MPC and DMAHDM were immobilized in the resin; they would not be released with time, which would ensure its sustained antibacterial capability. Second, NAg would be released to the surrounding environment to improve antibacterial property at the early stage as it could lead to bacterial cell death [34]. However, the release of NAg should not significantly affect $\mathrm{BMC}^{\prime}$ s mechanical properties since the NAg mass fraction was only $0.12 \%$ in the EBPM-NAg resin. Furthermore, $\mathrm{Ca}$ and $\mathrm{P}$ ion release from NACP would indeed leave nano-voids in the restoration. However, the BMC can be repeatedly recharged with Ca and P ions [40], which would fill these voids and potentially maintain its mechanical properties. Further studies are needed to investigate whether the mechanical properties could be maintained in the long term.

Tooth root caries is a growing public health issue due to the rapid increase in the elderly population coupled with increases in tooth retention in seniors [14,15], Gingival recession can increase the susceptibility to root caries [16]. Furthermore, low salivary flow further contributes to biofilm and plaque buildup and the occurrence of root caries. However, Class V restorations with subgingival margins may be difficult to clean and this in turn could enhance the development of periodontitis and the loss of the tooth's attachment [10]. Moreover, the process of dental caries is that acid-producing bacteria feed on fermentable carbohydrates and produce organic acids as byproducts [5], and these acids dissolve hydroxyapatite minerals to form caries [6]. Glass ionomer cements are often used in Class $\mathrm{V}$ restorations due to their good biocompatibility with dental pulp tissues and fluoride release. However, previous studies indicated that a commercial resin-modified glass ionomer was not potent enough to inhibit bacterial growth and biofilm formation [22]. In addition, glass ionomer cement was relatively less esthetic for anterior teeth and cervical lesions [50]. Therefore, the present study focused on developing an antibacterial and remineralizing composite for Class $\mathrm{V}$ restorations, because it is highly desirable to develop a novel multifunctional composite for Class $\mathrm{V}$ restoration to achieve remineralization to strengthen and protect the root structures, while being able to inhibit cariogenic and periodontitis-related pathogens.

A previous study showed that 3\% DMAHDM + 3\% MPC in the composite achieved substantial reduction in biofilm growth, metabolic activity and polysaccharide production [10]. Biofilm CFU counts were reduced by nearly four orders of magnitude for four species of periodontal pathogens [10]. However, the remineralization ability of this composite was not demonstrated. Another previous study showed that PAMAM + NACP composite induced great coronal dentin remineralization in a cyclic artificial saliva/lactic acid solution regimen [39]. The combination of NACP with PAMAM achieved triple benefits of excellent nucleation templates, high $\mathrm{Ca}$ and $\mathrm{P}$ ion concentrations, and acid-neutralization [39]. However, the remineralization of root dentin had not been investigated in previous studies.

It is highly promising that combination of NAg, MPC, DMAHDM, NACP, and PAMAM could promote further remineralization. First, salivary proteins adsorbed onto the material surface in the oral environment provide the medium for the attachment of bacteria [51]. Therefore, making a protein-repellent composite would help repel bacterial attachment. MPC polymer has been shown to 
have excellent resistance to protein adsorption and bacterial adhesion [52]. MPC is highly hydrophilic and there is an abundance of free water but no bound water in the hydrated MPC polymer [27,28]. The large amount of free water around the phosphorylcholine group is considered to help detach proteins [52]. MPC polymer can repel protein adsorption and inhibit bacterial adhesion, thus reducing biofilm growth. Second, QAMs and NAg were both shown to be antibacterial, and the mode of antibacterial action for QAMs is suggested to be contact-inhibition [53]. The positively charged quaternary amine $\mathrm{N}+$ interacts with the negatively charged cell membrane of bacteria, leading to membrane disruption and cytoplasmic leakage [53]. MPC could repel the proteins from covering the composite surface, leading to direct contact of the composite surface with bacteria, thus enhancing the contact-killing efficacy. NAg is another effective antibacterial agent which has a strong toxicity to a wide range of microorganism [54]. Its antimicrobial mechanism appears to involve Ag ions interacting with and inactivating the vital enzymes of bacteria, causing the DNA in the bacteria to lose its replication ability, leading to cell death $[34,54]$. A previous study demonstrated that adding dual agents (QADM $+\mathrm{NAg}$ ) in the same composite resulted in a significantly stronger antibacterial capability than using QADM or NAg alone [34]. The combined use of MPC, DMAHDM and NAg greatly reduced biofilm growth and acid production, reducing biofilm CFU by three orders of magnitude, compared to commercial control [24]. In addition, NACP nanocomposite could greatly increase the $\mathrm{Ca}$ and $\mathrm{P}$ ion release at cariogenic low $\mathrm{pH}$, when these ions were most needed to inhibit caries [17]. Furthermore, NACP nanocomposite was a promising remineralization agent, which had an enamel lesion remineralization efficacy that was four-fold that of a commercial fluoride-releasing composite [55]. The NACP nanocomposite also reduced caries at the enamel-composite margins to $1 / 3$ that of a control composite under oral biofilms in a human in situ study [56,57]. Moreover, PAMAM could bind to demineralized dentin by electrostatic interactions and size-exclusion features of collagen fibrils [37]. During remineralization, PAMAM can attract Ca ions through Ca complexes via large numbers of amine groups on the external surface and amide groups in its branches [37]. Therefore, these previous studies justified the combined use of these agents (NAg, MPC, DMAHDM, NACP, and PAMAM) in the present study for maximum benefits in defeating dental caries. The present study focused on the development of the BMC and the remineralization ability on tooth root dentin. The antibacterial properties of this new combined approach will be investigated in a separate paper.

Most previous remineralization studies were performed at a neutral $\mathrm{pH}$ solution [58,59]. However, acids produced by oral biofilms or derived from acidic food can lower the local $\mathrm{pH}$ to 4.5 or 4 [60]. Hence, acid challenge should be taken into account in a remineralization study. In the present study, we employed a pH-cycling model to simulate the oral environment, and artificial saliva at $\mathrm{pH} 7$ for remineralization and lactic acid at $\mathrm{pH} 4$ for acid challenge were used [48]. Artificial saliva is the most common remineralization solution, and lactic acid accounts for the majority of biofilm acids [48]. In addition, a $\mathrm{pH}$ value of 4 for demineralization solution was also used in previous studies as an accelerated laboratory model [18]. Indeed, the local plaque $\mathrm{pH}$ could reach 4.5 or 4 , supporting the use of the $\mathrm{pH}$-cycling model to investigate remineralization [60].

Dentin hardness depends on the amount of calcified matrix per $\mathrm{mm}^{2}$ and the tubular density [61]. Hardness is an indirect measurement of mineral loss or gain in dental hard tissues [62]. Surface hardness recovery could provide evidence that remineralization occurred [27]. However, it has been reported that the hydration and dehydration of tissues may affect the mechanical properties of dentin $[63,64]$. Therefore, the mechanical properties of dentin should be evaluated on the fully hydrated tissues $[63,64]$. The cross-sectional hardness measured by nano-indentation may be more accurate to reflect dentin remineralization in the depth of dentin. In addition, elastic modulus is another important property of dentin that should be measured. Further study should measure the cross-sectional hardness and elastic modulus of demineralized and remineralized dentin using a nano-indentation method.

The results of $\mathrm{pH}$ and $\mathrm{Ca}$ and $\mathrm{P}$ ion release were similar to our previous study $[17,65-67]$. $\mathrm{BMC}$ rapidly increased the $\mathrm{pH}$ from 4 to above 5.5, and released large amount of $\mathrm{Ca}$ and $\mathrm{P}$ ions. The acid neutralization and $\mathrm{Ca}$ and $\mathrm{P}$ ion release of $\mathrm{BMC}$ should be attributed to the component of 
NACP. The control group showed a further demineralization and a decrease in root dentin hardness. In the present study, the remineralization of root dentin occurred during the 23-h immersion in artificial saliva at $\mathrm{pH} 7$, and then the regenerated minerals were challenged by lactic acid solution at $\mathrm{pH} 4$ for $1 \mathrm{~h}$ daily for 21 days. Therefore, the total remineralization effect depended on the rate of mineral regeneration in artificial saliva and the dissolution in lactic acid. It could be speculated that the demineralized root dentin alone could not induce effective remineralization during the immersion in artificial saliva due to its week nucleation ability, and the root dentin also could not resist the acid challenge because it did not have the acid-neutralization and $\mathrm{Ca}$ and $\mathrm{P}$ ion release capabilities. Hence, further demineralization occurred in root dentin in the control group. In addition, the further decrease in dentin hardness may also be partly attributed to the damage of the remaining collagen matrix in this severely demineralized outer zone. Dentin contains matrix metalloproteinases (MMPs) and cysteine cathespins, both of which could dissolve the collagen fibrils. These two types of enzymes may be activated as the dentin mineral is lost due to demineralization, thus degrading the collagen fibrils and further contributing to hardness loss $[68,69]$.

The BMC group showed a moderate remineralization, with mineral precipitation in root dentin and a greater hardness than the control. BMC released $\mathrm{Ca}$ and $\mathrm{P}$ ions, leading to higher ion concentrations when immersed in artificial saliva, which would benefit the remineralization. Furthermore, when immersed in lactic acid at $\mathrm{pH} 4$, BMC rapidly raised the $\mathrm{pH}$ to $>5.5$, and released a large amount of $\mathrm{Ca}$ and $\mathrm{P}$ ions, both of which could inhibit the demineralization of root dentin. However, the weak nucleation of root dentin limited the remineralization efficacy.

The PAMAM group had a remineralization effect similar to BMC group, although via a different mechanism. PAMAM macromolecules attracted $\mathrm{Ca}$ and $\mathrm{P}$ ions when immersed in artificial saliva, leading to rapid mineral regeneration. However, the remineralization effect of the present study, using a more realistic cyclic artificial saliva/lactic acid regimen, was much weaker than a previous study using constant $\mathrm{pH} 7$ [37]. This indicates that remineralization tests performed at neutral $\mathrm{pH}$ overestimate the effects of a remineralization agent, because in vivo conditions have frequent low $\mathrm{pH}$ acidic challenges. Therefore, caution should be exercised in explaining remineralization studies performed at neutral $\mathrm{pH}$.

In contrast, the novel BMC + PAMAM combined approach showed the most mineral regeneration and the greatest root dentin hardness, which reached the hardness of healthy root dentin. The combination of PAMAM with BMC achieved triple benefits of excellent nucleation templates, high $\mathrm{Ca}$ and $\mathrm{P}$ ion concentrations, and acid-neutralization. The results demonstrate the BMC + PAMAM method was effective in inhibiting root dentin demineralization and promote root dentin remineralization. It should be noted that the fast mineral deposition in the surface could lead to a hypermineralization phenomenon, which might prevent minerals from depositing into the deeper layers of dentin. Further study is needed to investigate whether hypermineralization occurred in the remineralization of demineralized dentin [70,71].

The novel BMC + PAMAM strategy could potentially be applied to various dental applications including, for example, root caries treatments. When root caries occurs, the Class V cavity could be filled with BMC, and then a PAMAM solution could be coated to cover the surrounding exposed root dentin, which achieved double benefits of demineralization inhibition and remineralization promotion. On the other hand, BMC is promising for Class V restorations to inhibit periodontal pathogens, combat periodontitis and protect the periodontium [10]. The combined use of BMC and PAMAM is beneficial for tooth root caries and protect tooth root structures, and is potentially applicable to Classes I, II and other types of tooth cavity restorations. Further studies are needed to investigate the novel $\mathrm{BMC}+$ PAMAM strategy in antibacterial and caries-inhibition tests for various dental restorations.

\section{Conclusions}

This study developed a novel bioactive multifunctional composite (BMC) for Class V restorations with a combination of remineralization, protein-repellent and antibacterial capabilities, and investigated 
the effects of this BMC and poly (amido amine) PAMAM on remineralization of demineralized root dentin in a cyclic artificial saliva/lactic acid for the first time. BMC + PAMAM was identified as the most effective method to inhibit root dentin demineralization and promote root dentin remineralization. BMC + PAMAM regenerated root dentin minerals and returned the pre-demineralized root dentin hardness to the level of healthy root dentin. The method of BMC + PAMAM is promising for a wide range of dental applications to combat caries and remineralize and protect tooth structures.

Acknowledgments: This work was supported by NIH R01 DE17974 (H.H.K.X.), National Natural Science Foundation of China 81141062 (Y.D.), University of Maryland School of Dentistry bridging fund (H.H.K.X.) and University of Maryland seed grant (H.H.K.X.).

Author Contributions: Shimeng Xiao, Kunneng Liang and Michael D. Weir performed the experiments and obtained the figures. Hockin H. K. Xu and Yi Ding proposed the topic of this study and supervised the research including experimental design and data analyses, in discussions with Lei Cheng, Huaibing Liu, and Xuedong Zhou. Hockin H. K. Xu and Shimeng Xiao wrote the initial manuscript in discussions with all co-authors. All authors read and approved the final manuscript.

Conflicts of Interest: The authors declare no conflict of interest.

\section{References}

1. Ten, C.J.; Featherstone, J. Mechanistic aspects of the interactions between fluoride and dental enamel. Crit. Rev. Oral Biol. Med. 1991, 2, 283-296.

2. Hicks, J.; Garcia-Godoy, F.; Flaitz, C. Biological factors in dental caries: Role of saliva and dental plaque in the dynamic process of demineralization and remineralization (part 1). J. Clin. Pediatr. Dent. 2004, 28, 47-52. [CrossRef]

3. Kidd, E.; Fejerskov, O. What constitutes dental caries? Histopathology of carious enamel and dentin related to the action of cariogenic biofilms. J. Dent. Res. 2004, 83, C35-C38. [CrossRef] [PubMed]

4. Hicks, J.; Garcia-Godoy, F.; Flaitz, C. Biological factors in dental caries: Role of remineralization and fluoride in the dynamic process of demineralization and remineralization (part 3). J. Clin. Pediatr. Dent. 2004, 28, 203-214. [CrossRef] [PubMed]

5. Geddes, D. Acids produced by human dental plaque metabolism in situ. Caries Res. 1975, 9, 98-109. [CrossRef] [PubMed]

6. Silverstone, L. Structure of carious enamel, including the early lesion. Oral Sci. Rev. 1973, 3, 100. [PubMed]

7. Featherstone, J. Remineralization, the natural caries repair process-The need for new approaches. Adv. Dent. Res. 2009, 21, 4-7. [CrossRef] [PubMed]

8. Ferracane, J.L. Resin composite-State of the art. Dent. Mater. 2011, 27, 29-38. [CrossRef] [PubMed]

9. Drummond, J.L. Degradation, fatigue, and failure of resin dental composite materials. J. Dent. Res. 2008, 87, 710-719. [CrossRef] [PubMed]

10. Wang, L.; Xie, X.; Imazato, S.; Weir, M.D.; Reynolds, M.A.; Xu, H.H. A protein-repellent and antibacterial nanocomposite for Class-V restorations to inhibit periodontitis-related pathogens. Mat. Sci. Eng. C Mater. 2016, 67, 702-710. [CrossRef] [PubMed]

11. Zalkind, M.M.; Keisar, O.; Hadani, P.; Grinberg, R.; Sela, M.N. Accumulation of Streptococcus mutans on Light-Cured Composites and Amalgam: An In Vitro Study. J. Esthet. Restor. Dent. 1998, 10, 187-190. [CrossRef]

12. Beyth, N.; Domb, A.J.; Weiss, E.I. An in vitro quantitative antibacterial analysis of amalgam and composite resins. J. Dent. 2007, 35, 201-206. [CrossRef] [PubMed]

13. Curzon, M.; Preston, A. Risk groups: Nursing bottle caries/caries in the elderly. Caries. Res. 2003, 38, $24-33$. [CrossRef] [PubMed]

14. Griffin, S.; Griffin, P.; Swann, J.; Zlobin, N. Estimating rates of new root caries in older adults. J. Dent. Res. 2004, 83, 634-638. [CrossRef] [PubMed]

15. Zhang, N.; Melo, M.A.S.; Chen, C.; Liu, J.; Weir, M.D.; Bai, Y.; Xu, H.H.K. Development of a multifunctional adhesive system for prevention of root caries and secondary caries. Dent. Mater. 2015, 31, 1119-1131. [CrossRef] [PubMed] 
16. Banting, D.W.; Papas, A.; Clark, D.C.; Proskin, H.M.; Schultz, M.; Perry, R. The effectiveness of $10 \%$ chlorhexidine varnish treatment on dental caries incidence in adults with dry mouth. Gerodontology 2000, 17, 67-76. [CrossRef] [PubMed]

17. Xu, H.H.; Moreau, J.L.; Sun, L.; Chow, L.C. Nanocomposite containing amorphous calcium phosphate nanoparticles for caries inhibition. Dent. Mater. 2011, 27, 762-769. [CrossRef] [PubMed]

18. Langhorst, S.; O’Donnell, J.; Skrtic, D. In vitro remineralization of enamel by polymeric amorphous calcium phosphate composite: Quantitative microradiographic study. Dent. Mater. 2009, 25, 884-891. [CrossRef] [PubMed]

19. Moreau, J.L.; Sun, L.; Chow, L.C.; Xu, H.H. Mechanical and acid neutralizing properties and bacteria inhibition of amorphous calcium phosphate dental nanocomposite. J. Biomed. Mater. Res. B 2011, 98, 80-88. [CrossRef] [PubMed]

20. Cheng, L.; Weir, M.; Zhang, K.; Xu, S.; Chen, Q.; Zhou, X.; Xu, H. Antibacterial nanocomposite with calcium phosphate and quaternary ammonium. J. Dent. Res. 2012, 91, 460-466. [CrossRef] [PubMed]

21. Xie, D.; Weng, Y.; Guo, X.; Zhao, J.; Gregory, R.L.; Zheng, C. Preparation and evaluation of a novel glass-ionomer cement with antibacterial functions. Dent. Mater. 2011, 27, 487-496. [CrossRef] [PubMed]

22. Zhang, N.; Chen, C.; Weir, M.D.; Bai, Y.; Xu, H.H. Antibacterial and protein-repellent orthodontic cement to combat biofilms and white spot lesions. J. Dent. 2015, 43, 1529-1538. [CrossRef] [PubMed]

23. Imazato, S. Bio-active restorative materials with antibacterial effects: New dimension of innovation in restorative dentistry. Dent. Mater. J. 2009, 28, 11-19. [CrossRef] [PubMed]

24. Zhang, N.; Weir, M.D.; Chen, C.; Melo, M.A.; Bai, Y.; Xu, H.H. Orthodontic cement with protein-repellent and antibacterial properties and the release of calcium and phosphate ions. J. Dent. 2016, 50, 51-59. [CrossRef] [PubMed]

25. Li, F.; Weir, M.; Xu, H. Effects of quaternary ammonium chain length on antibacterial bonding agents. J. Dent. Res. 2013, 92, 932-938. [CrossRef] [PubMed]

26. Namba, N.; Yoshida, Y.; Nagaoka, N.; Takashima, S.; Matsuura-Yoshimoto, K.; Maeda, H.; van Meerbeek, B.; Suzuki, K.; Takashiba, S. Antibacterial effect of bactericide immobilized in resin matrix. Dent. Mater. 2009, 25, 424-430. [CrossRef] [PubMed]

27. Wu, D.; Yang, J.; Li, J.; Chen, L.; Tang, B.; Chen, X.; Wu, W.; Li, J. Hydroxyapatite-anchored dendrimer for in situ remineralization of human tooth enamel. Biomaterials 2013, 34, 5036-5047. [CrossRef] [PubMed]

28. Ishihara, K.; Ueda, T.; Nakabayashi, N. Preparation of phospholipid polymers and their properties as polymer hydrogel membranes. Polym. J. 1990, 22, 355-360. [CrossRef]

29. Zhang, N.; Zhang, K.; Melo, M.A.S.; Chen, C.; Fouad, A.F.; Bai, Y.; Xu, H.H. Novel protein-repellent and biofilm-repellent orthodontic cement containing 2-methacryloyloxyethyl phosphorylcholine. J. Biomed. Mater. Res. B 2016, 104, 949-959. [CrossRef] [PubMed]

30. Zhang, N.; Weir, M.D.; Romberg, E.; Bai, Y.; Xu, H.H. Development of novel dental adhesive with double benefits of protein-repellent and antibacterial capabilities. Dent. Mater. 2015, 31, 845-854. [CrossRef] [PubMed]

31. Zhang, K.; Melo, M.A.S.; Cheng, L.; Weir, M.D.; Bai, Y.; Xu, H.H. Effect of quaternary ammonium and silver nanoparticle-containing adhesives on dentin bond strength and dental plaque microcosm biofilms. Dent. Mater. 2012, 28, 842-852. [CrossRef] [PubMed]

32. Cheng, Y.J.; Zeiger, D.N.; Howarter, J.A.; Zhang, X.; Lin, N.J.; Antonucci, J.M.; Lin-Gibson, S. In situ formation of silver nanoparticles in photocrosslinking polymers. J. Biomed. Mater. Res. B 2011, 97, 124-131. [CrossRef] [PubMed]

33. Morones, J.R.; Elechiguerra, J.L.; Camacho, A.; Holt, K.; Kouri, J.B.; Ramírez, J.T.; Yacaman, M.J. The bactericidal effect of silver nanoparticles. Nanotechnology 2005, 16, 2346. [CrossRef] [PubMed]

34. Cheng, L.; Zhang, K.; Zhou, C.-C.; Weir, M.D.; Zhou, X.-D.; Xu, H.H. One-year water-ageing of calcium phosphate composite containing nano-silver and quaternary ammonium to inhibit biofilms. Int. J. Oral Sci. 2016. [CrossRef] [PubMed]

35. Slenters, T.V.; Hauser-Gerspach, I.; Daniels, A.U.; Fromm, K.M. Silver coordination compounds as light-stable, nano-structured and anti-bacterial coatings for dental implant and restorative materials. J. Mater. Chem. 2008, 18, 5359-5362. [CrossRef]

36. Li, J.; Yang, J.; Li, J.; Chen, L.; Liang, K.; Wu, W.; Chen, X.; Li, J. Bioinspired intrafibrillar mineralization of human dentine by PAMAM dendrimer. Biomaterials 2013, 34, 6738-6747. [CrossRef] [PubMed] 
37. Liang, K.; Yuan, H.; Li, J.; Yang, J.; Zhou, X.; He, L.; Cheng, L.; Gao, Y.; Xu, X.; Zhou, X. Remineralization of Demineralized Dentin Induced by Amine-Terminated PAMAM Dendrimer. Macromol. Mater. Eng. 2015, 300, 107-117.

38. Zhang, H.; Yang, J.; Liang, K.; Li, J.; He, L.; Yang, X.; Peng, S.; Chen, X.; Ding, C.; Li, J. Effective dentin restorative material based on phosphate-terminated dendrimer as artificial protein. Colloid Surf. B 2015, 128, 304-314. [CrossRef] [PubMed]

39. Liang, K.; Weir, M.D.; Xie, X.; Wang, L.; Reynolds, M.A.; Li, J.; Xu, H.H. Dentin remineralization in acid challenge environment via PAMAM and calcium phosphate composite. Dent. Mater. 2016, 32, 1429-1440. [CrossRef] [PubMed]

40. Zhang, L.; Weir, M.D.; Chow, L.C.; Antonucci, J.M.; Chen, J.; Xu, H.H. Novel rechargeable calcium phosphate dental nanocomposite. Dent. Mater. 2016, 32, 285-293. [CrossRef] [PubMed]

41. Cheng, L.; Weir, M.D.; Xu, H.H.; Antonucci, J.M.; Kraigsley, A.M.; Lin, N.J.; Lin-Gibson, S.; Zhou, X. Antibacterial amorphous calcium phosphate nanocomposites with a quaternary ammonium dimethacrylate and silver nanoparticles. Dent. Mater. 2012, 28, 561-572. [CrossRef] [PubMed]

42. Cheng, L.; Zhang, K.; Melo, M.A.; Weir, M.; Zhou, X.; Xu, H. Anti-biofilm dentin primer with quaternary ammonium and silver nanoparticles. J. Dent. Res. 2012, 91, 598-604. [CrossRef] [PubMed]

43. Antonucci, J.M.; Zeiger, D.N.; Tang, K.; Lin-Gibson, S.; Fowler, B.O.; Lin, N.J. Synthesis and characterization of dimethacrylates containing quaternary ammonium functionalities for dental applications. Dent. Mater. 2012, 28, 219-228. [CrossRef] [PubMed]

44. Zhou, C.; Weir, M.D.; Zhang, K.; Deng, D.; Cheng, L.; Xu, H.H. Synthesis of new antibacterial quaternary ammonium monomer for incorporation into CaP nanocomposite. Dent. Mater. 2013, 29, 859-870. [CrossRef] [PubMed]

45. Tomalia, D.; Baker, H.; Dewald, J.; Hall, M.; Kallos, G.; Martin, S.; Roeck, J.; Ryder, J.; Smith, P. A new class of polymers: Starburst-dendritic macromolecules. Polym. J. 2002, 34, 132-147. [CrossRef]

46. Liang, K.; Gao, Y.; Li, J.; Liao, Y.; Xiao, S.; Zhou, X.; Li, J. Biomimetic mineralization of collagen fibrils induced by amine-terminated PAMAM dendrimers-PAMAM dendrimers for remineralization. J. Biomat. Sci. Polym. 2015, 26, 963-974. [CrossRef] [PubMed]

47. Tay, F.R.; Pashley, D.H. Guided tissue remineralisation of partially demineralised human dentine. Biomaterials 2008, 29, 1127-1137. [CrossRef] [PubMed]

48. Ten Cate, J.; Duijsters, P. Alternating demineralization and remineralization of artificial enamel lesions. Caries Res. 1982, 16, 201-210. [CrossRef] [PubMed]

49. Regnault, W.F.; Icenogle, T.B.; Antonucci, J.M.; Skrtic, D. Amorphous calcium phosphate/urethane methacrylate resin composites. I. Physicochemical characterization. J. Mater. Sci. Mater. Med. 2008, 19,507-515. [CrossRef] [PubMed]

50. Hayes, M.; Brady, P.; Burke, F.M.; Allen, P.F. Failure rates of class V restorations in the management of root caries in adults-a systematic review. Gerodontology 2016, 33, 299-307. [CrossRef] [PubMed]

51. Hori, K.; Matsumoto, S. Bacterial adhesion: From mechanism to control. Biochem. Eng. J. 2010, 48, 424-434. [CrossRef]

52. Goda, T.; Konno, T.; Takai, M.; Ishihara, K. Photoinduced phospholipid polymer grafting on Parylene film: Advanced lubrication and antibiofouling properties. Colloid Surf. B 2007, 54, 67-73. [CrossRef] [PubMed]

53. Beyth, N.; Yudovin-Farber, I.; Bahir, R.; Domb, A.J.; Weiss, E.I. Antibacterial activity of dental composites containing quaternary ammonium polyethylenimine nanoparticles against $\mathrm{Streptococcus} \mathrm{mutans.}$ Biomaterials 2006, 27, 3995-4002. [CrossRef] [PubMed]

54. Rai, M.; Yadav, A.; Gade, A. Silver nanoparticles as a new generation of antimicrobials. Biotechnol. Adv. 2009, 27, 76-83. [CrossRef] [PubMed]

55. Weir, M.; Chow, L.; Xu, H. Remineralization of demineralized enamel via calcium phosphate nanocomposite. J. Dent. Res. 2012, 91, 979-984. [CrossRef] [PubMed]

56. Melo, M.A.S.; Weir, M.D.; Rodrigues, L.K.; Xu, H.H. Novel calcium phosphate nanocomposite with caries-inhibition in a human in situ model. Dent. Mater. 2013, 29, 231-240. [CrossRef] [PubMed]

57. Xie, X.; Wang, L.; Xing, D.; Arola, D.D.; Weir, M.D.; Bai, Y.; Xu, H.H. Protein-repellent and antibacterial functions of a calcium phosphate rechargeable nanocomposite. J. Dent. 2016, 52, 15-22. [CrossRef] [PubMed]

58. Rahiotis, C.; Vougiouklakis, G. Effect of a CPP-ACP agent on the demineralization and remineralization of dentine in vitro. J. Dent. 2007, 35, 695-698. [CrossRef] [PubMed] 
59. Guo, B.; Que, K.; Jing, Y.; Wang, B.; Liang, Q.; Xie, H. Effect of Galla chinensis on the remineralization of two bovine root lesions morphous in vitro. Int. J. Oral Sci. 2012, 4, 152-156. [CrossRef] [PubMed]

60. Jensen, M.; Schachtele, C. The acidogenic potential of reference foods and snacks at interproximal sites in the human dentition. J. Dent. Res. 1983, 62, 889-892. [CrossRef] [PubMed]

61. Pashley, D.; Okabe, A.; Parham, P. The relationship between dentin microhardness and tubule density. Endod. Dent. Traumatol. 1985, 1, 176-179. [CrossRef] [PubMed]

62. Celik, E.U.; Ergücü, Z.; Türkün, L.S.; Türkün, M. Effect of different laser devices on the composition and microhardness of dentin. Oper. Dent. 2008, 33, 496-501. [CrossRef] [PubMed]

63. Burwell, A.K.; Thula-Mata, T.; Gower, L.B.; Habelitz, S.; Kurylo, M.; Ho, S.P.; Chien, Y.C.; Cheng, J.; Cheng, N.F.; Gansky, S.A. Functional remineralization of dentin lesions using polymer-induced liquid-precursor process. PLoS ONE 2012, 7, e38852. [CrossRef] [PubMed]

64. Bertassoni, L.E.; Habelitz, S.; Kinney, J.H.; Marshall, S.J.; Marshall, G.W. Biomechanical Perspective on the Remineralization of Dentin. Caries Res. 2009, 43, 70. [CrossRef] [PubMed]

65. Cheng, L.; Weir, M.D.; Xu, H.H.; Antonucci, J.M.; Lin, N.J.; Lin-Gibson, S.; Xu, S.M.; Zhou, X. Effect of amorphous calcium phosphate and silver nanocomposites on dental plaque microcosm biofilms. J. Biomed. Mater. Res. B 2012, 100, 1378-1386. [CrossRef] [PubMed]

66. Wu, J.; Weir, M.D.; Melo, M.A.S.; Xu, H.H. Development of novel self-healing and antibacterial dental composite containing calcium phosphate nanoparticles. J. Dent. 2015, 43, 317-326. [CrossRef] [PubMed]

67. Cheng, L.; Weir, M.D.; Zhang, K.; Wu, E.J.; Xu, S.M.; Zhou, X.; Xu, H.H. Dental plaque microcosm biofilm behavior on calcium phosphate nanocomposite with quaternary ammonium. Dent. Mater. 2012, 28, 853-862. [CrossRef] [PubMed]

68. Heras, M.D.L.; Valenzuela, A.; Overall, C.M. The matrix metalloproteinase gelatinase A in human dentine. Arch. Oral. Biol. 2000, 45, 757-765. [CrossRef]

69. Nascimento, F.D.; Minciotti, C.L.; Geraldeli, S.; Carrilho, M.R.; Pashley, D.H.; Tay, F.R.; Nader, H.B.; Salo, T.; Tjäderhane, L.; Tersariol, I.L. Cysteine cathepsins in human carious dentin. J. Dent. Res. 2011, 90, 506-511. [CrossRef] [PubMed]

70. Ten Cate, J.M.; van Duinen, R.N. Hypermineralization of dentinal lesions adjacent to glass-ionomer cement restorations. J. Dent. Res. 1995, 74, 1266-1271. [CrossRef] [PubMed]

71. Kawasaki, K.; Ruben, J.; Tsuda, H.; Huysmans, M.C.D.N.J.M.; Takagi, O. Relationship between Mineral Distributions in Dentine Lesions and Subsequent Remineralization in vitro. Caries Res. 2000, 34, 395-403. [CrossRef] [PubMed]

(C) 2017 by the authors; licensee MDPI, Basel, Switzerland. This article is an open access article distributed under the terms and conditions of the Creative Commons Attribution (CC BY) license (http://creativecommons.org/licenses/by/4.0/). 